\title{
Selected Bibliography of Socialist Famines in the Twentieth Century
}

\section{Andrea Graziosi}

National Agency for the Evaluation of Universities and Research Institutes, Rome

"A New Cult of Personality: Suslov's Secret Report on Mao, Khrushchev, and Sino-Soviet Tensions, December 1959." CWIHP Bulletin 8/9 (1996-97): 244-48. Print.

Abylkhozhin, Z., K. Aldazhumanov, and M. Kozybaev, eds. Kollektivizatsiia v Kazakhstane: Tragediia krest'ianstva. Alma-Ata: Biblioteka istorika, 1992. Print.

Abylkhozhin, Z., M. Kozybaev, and M. Tatimov. "Kazakhstanskaia tragediia." Voprosy istorii, 1989, no. 7: 53-71. Print.

Afanas'ev, Iu. N., ed. Golod 1932-1933 godov. Moscow: Rossiiskii gosudarstvennyi gumanitarnyi universitet, 1995. Print.

Agarev, A. F., ed. Tragicheskaia avantiura: Sel'skoe khoziaistvo Riazanskoi oblasti 1950-1960 gg.: A. N. Larionov, N. S. Khrushchev i drugie. Dokumenty, sobytiia, fakty. Riazan': Russkoe slovo, 2005. Print.

Aldazhumanov, K. S., et al., eds. Nasil'stvennaia kollektivizatsiia i golod v Kazakhstane v 1931-1933 gg.: Sbornik dokumentov i materialov. Almaty: Fond XXI vek, 1998. Print.

Andreev, E. M., L. E. Darskii, and T. L. Khar'kova. Demograficheskaia istoriia Rossiiskoi Federatsii, 1927-1959. Moscow: Informatika, 1998. Print.

Andriewsky, Olga. "Towards a Decentred History: The Study of the Holodomor and Ukrainian Historiography." East/West: Journal of Ukrainian Studies 2.1 (2015): 17-52. Web. DOI: http://dx.doi.org/10.21226/T2301N.

Applebaum, Anne. Gulag: A History. New York: Doubleday, 2003. Print.

Basciani, Alberto. "From Collectivization to the Great Famine: Eyewitness Statements on the Holodomor by Refugees from the Ukrainian SSR, 1930-1933." Holodomor Studies 3, nos. 1-2 (2011): 1-27. Print.

Becker, Jasper. Hungry Ghosts: Mao's Secret Famine. New York: The Free Press, 1996. Print.

Belov, Fedor. The History of a Soviet Collective Farm. New York: Praeger, 1955.

Berelovich, A., and V. P. Danilov, eds. Sovetskaia derevnia glazami VChKOGPU-NKVD, 1918-1939. Dokumenty i materialy v 4 tomakh. Vol. 3. 1930-1934. Moscow: Rossiiskaia politicheskaia entsiklopediia, 2003. 
Bernstein, Thomas. P. "Mao Zedong and the Famine of 1959-1960: A Study in Wilfulness." The China Quarterly, no. 186 (June 2006): 421-45. Print.

Beznin, M. A., and T. M. Dimoni. "Povinnosti rossiiskikh kolkhoznikov v 1930-1960-e gody." Otechestvennaia istoriia, 2002, no. 2: 96-111. Print. Bianco, Lucien. "Carestie comuniste: Urss, 1931-33; Cina, 1958-1962." Contemporanea, 2015, no. 1: 157-74. Print.

---. “Communisme et famine: URSS, 1931-1933; Chine 1958-1962.” Journée d'étude INALCO-EHESS "Famines soviétique et chinoise." Paris, 18 October 2013. Paper presentation.

---. La récidive: Révolution russe, Révolution chinoise. Paris: Gallimard, 2014. Print.

Blum, Alain, and Martine Mespoulet. L'anarchie bureaucratique: Statistique et pouvoir sous Staline. Paris: La Découverte, 2003. Print.

Boyko, D., et al, eds. Holodomor: The Great Famine in Ukraine, 1932-1933. Warsaw and Kyiv: Institute of National Remembrance, 2009. Print.

Brutskus, B. Sotsialisticheskoe khoziastvo: Teoreticheskie mysli po povodu russkogo opyta. Berlin: Tritemis, 1923. Print.

--- (Brutzkus). Economic Planning in Soviet Russia. London: Routledge, 1935. Print.

Cameron, Sarah. The Hungry Steppe: Famine, Mass Violence and the Making of Soviet Kazakhstan (Forthcoming).

Caroli, Dorena. L'enfance abandonnée et délinquante dans la Russie soviétique, 1917-1937. Paris: L'Harmattan, 2004. Print.

Carynnyk, Marco, et al., eds. The Foreign Office and the Famine: British Documents on Ukraine and the Great Famine of 1932-1933. Kingston, Ont.: Limestone Press, 1988. Print.

Chan, Alfred L. Mao's Crusade: Politics and Policy Implementation in China's Great Leap Forward. New York: Oxford UP, 2001. Print.

Chang, Gene Hsin, and Guangzhong James Wen. "Communal Dining and the Chinese Famine of 1958-1961." Economic Development and Cultural Change 46.1 (October 1997): 1-34. Print.

Chlevnjuk [Khlevniuk], 0. V. "Stalin e la carestia sovietica dei primi anni Trenta." Storica, no. 32 (2005): 27-40. Print.

Commission on the Ukrainian Famine. Investigation of the Ukrainian Famine, 1932-1933: Report to Congress. Adopted by the Commission, April 19, 1988, Submitted to Congress, April 22, 1988 Washington, D.C.: U.S. G.P.O., 1988. Print.

Conquest, Robert. The Harvest of Sorrow: Soviet Collectivization and the Terror-Famine. New York: Oxford UP; Edmonton: The U of Alberta Press in association with the Can. Inst. of Ukrainian Studies, 1986. Print. 
Curran, Declan, Lubomyr Luciuk, and Andrew G. Newby, eds. Famines in European Economic History: The Last Great European Famines Reconsidered. London: Routledge, 2015. Print.

Danilov, V.P., Roberta Manning, and Lynne Viola. Tragediia sovetskoi derevni: Kollektivizatsiia i raskulachivanie. Dokumenty $i$ materialy $v 5$ tomakh, 1927-1939. Vol. 3. Moscow: ROSSPEN, 2001. Print.

Dalrymple, Dana G. “The Soviet Famine of 1932-1934." Soviet Studies 15.3 (January 1964): 250-84; and 16.4 (1965): 471-74. Print.

Danylenko, Vasyl', et al., eds. Rozsekrechena pam'iat': Holodomor 1932-1933 rokiv v Ukraïni v dokumentakh GPU-NKVD. Kyiv: Stylos, 2007. Print.

Davies, R. W., Mark Harrison, and S. G. Weathcroft eds. The Economic Transformation of the Soviet Union. Cambridge: Cambridge UP, 1994. Print.

Davies, R. W., et al., comps. and eds. The Stalin-Kaganovich Correspondence, 1931-1936. New Haven: Yale UP, 2003. Print.

Davies, R. W., and S. G. Weathcroft. The Years of Hunger: Soviet Agriculture, 1931-1933. Basingstoke and New York: Palgrave Macmillan, 2004. Print.

Khlevniuk, Oleg, and R. W. Davies "The End of Rationing in the Soviet Union, 1934-1935." Europe-Asia Studies 51.4 (May 1999): 557-609. Print.

Dikötter, Frank. Mao's Great Famine: The History of China's Most Devastating Catastrophe, 1958-1962. London: Bloomsbury; New York: Walker, 2011. Print.

---. The Tragedy of Liberation: A History of the Chinese Revolution, 19451957. London: Bloomsbury, 2013. Print.

Dittmer, Lowell. "Death and Transfiguration: Liu Shaoqi's Rehabilitation and Contemporary Chinese Politics." The Journal of Asian Studies 40.3 (May 1981): 455-79. Print.

Dolot, Myron. Execution by Hunger: The Hidden Holocaust. New York: Norton, 1985. Print.

Domenach, Jean-Luc. Chine: L'archipel oublié. Paris: Fayard, 1992. Print.

Domes, Jürgen. Peng Te-huai: The Man and the Image. London: Hurst, 1985. Print.

Drèze, Jean, and Amartya Sen. India: Economic Development and Social Opportunity. New York: Oxford UP, 1995. Print.

MacFarquhar, Roderick. The Origins of the Cultural Revolution. 3 vols. New York: Columbia UP, 1974-97. Print.

Felshtinsky, Yuri. "Lenin, Trotsky, Stalin and the Left Opposition in the USSR, 1918-1928." Cahiers du monde russe et soviétique 31.4 (1990): 569-78. Print.

Fisher, Harold H. The Famine in Soviet Russia, 1919-1923: The Operations of the American Relief Administration. New York: MacMillan, 1927. Print. 
Fitzpatrick, Sheila. Stalin's Peasants: Resistance and Survival in the Russian Village after Collectivization. New York: Oxford UP, 1994. Print.

Gamache, Ray. Gareth Jones: Eyewitness to the Holodomor. Cardiff: Welsh Academic Press, 2013. Print.

Garnaut, Anthony. "The Geography of the Great Leap Famine." Modern China 40.3 (2014): 315-48. Print.

Goland, Iu. M. Krizisy, razrushivshie NEP: Valiutnoe regulirovanie v period NEPa. Moscow: Fond ekonomicheskoi knigi "Nachala," 1998. Print.

Graziosi, Andrea. "Collectivisation, révoltes paysannes et politiques gouvernementales à travers les rapports du GPU d'Ukraine de févriermars 1930." Cahiers du monde russe 35.3 (1994): 437-72. Print.

---. The Great Soviet Peasant War: Bolsheviks and Peasants, 1918-1933. Cambridge, Mass.: Harvard Ukrainian Research Institute, 1996. Print.

---. "The Impact of Holodomor Studies on the Understanding of the USSR." East/West: Journal of Ukrainian Studies 2.1 (2015): 53-79. Web. DOI: http://dx.doi.org/10.21226/T2Z595.

---. A New Peculiar State: Explorations in Soviet History, 1917-1937. Westport, Conn.: Praeger, 2000. Print.

---. "The Soviet 1931-1933 Famines and the Ukrainian Holodomor: Is a New Interpretation Possible, and What Would Its Consequences Be?" Hunger by Design: The Great Ukrainian Famine and Its Soviet Context. Ed. Halyna Hryn. Cambridge, Mass.: Harvard Ukrainian Research Institute, 2008. 1-19. Print.

---. "Stalin, krest'ianstvo i gosudarstvennyi sotsializm: Evoliutsiia vzaimootnoshenii, 1927-1951 gg." Istoriia Stalinizma: Krest'ianstvo $i$ vlast'. Moscow: Rossiiskaia politicheskaia entsiklopediia, 2011. 12-32. Print.

---. "The Soviet 1931-33 Famines and the Ukrainian Holodomor: Is a New Interpretation Possible, What Would Its Consequences Be?" Hunger by Design: The Great Ukrainian Famine and Its Soviet Context. Ed. Halyna Hryn. Cambridge, Mass: Ukrainian Research Institute, Harvard University, 2008. 1-19. Print.

---. L'Urss dal trionfo al degrado: Storia dell'Unione Sovietica, 1945-1991. Bologna: Società editrice il Mulino, 2008. Print.

---. L'Urss di Lenin e Stalin: Storia dell'Unione Sovietica, 1914-1945. Bologna: Società editrice il Mulino, 2007. Print.

---. "The Uses of Hunger: Stalin's Solution of the Peasant and National Questions in Soviet Ukraine, 1932-1933." Famines in European Economic History. Ed. Declan Curran, Lubomyr Luciuk, and Andrew G. Newby. New York: Routledge, 2015. 223-60. Print. 
---, ed. Lettere da Kharkov: La carestia in Ucraina e nel Caucaso del Nord nei rapporti dei diplomatici italiani, 1932-33. Turin: Giulio Einaudi Editore, 1991. Print.

---, Lubomyr Hajda, and Halyna Hryn, eds. After the Holodomor: The Enduring Impact of the Great Famine in Ukraine. Cambridge, Mass.: Ukrainian Research Institute, Harvard University, $2013=$ Harvard Ukrainian Studies 30.1-4 (2008). Print.

---, and Iurii Shapoval, eds. Lysty z Kharkova: Holod $v$ Ukraïni ta na Pivnichnomu Kavkazi v povidomlenniakh italiis'kykh dyplomativ 19321933 rokiv. Trans. Mar'iana. Prokopovych. Kharkiv; Folio, 2007. Print.

Gupta, S. D., ed. The Ryutin Platform: Stalin and the Crisis of Proletarian Dictatorship. Platform of the "Union of Marxists-Leninists." Trans. Pranab Ghosh and Susmita Bhattachary. South 24 Parganas: Seribaan, 2010. Print.

Haggard, Stephan, and Marcus. Noland. Famine in North Korea: Markets, Aid, and Reform. New York: Columbia UP, 2007. Print.

Heller, Klaus, and Jan Plamper, eds. Personality Cults in Stalinism. Göttingen: V\&R Unipress, 2004. Print.

Hessler, Julie. A Social History of Soviet Trade: Trade Policy, Retail Practices, and Consumption, 1917-1953. Princeton: Princeton UP, 2004. Print.

Hrynevych, Liudmyla. Khronika kolektyvizatsiï ta Holodomoru v Ukraïni, 1927-1933. Vol. 1, bks. 1-3. Kyiv: Krytyka, 2008-12. Print.

Isajiw, Wsevolod, ed. Famine-Genocide in Ukraine, 1932-1933: Western Archives, Testimonies and New Research. Toronto: Ukrainian Canadian Research and Documentation Centre, 2003. Print.

Ivnitskii, N. A. Golod 1932-1933 godov v SSSR: Ukraina, Kazakhstan, Severnyi Kavkaz, Povol'zhe, Tsentral'no-Chernozemnaia oblast', Zapadnaia Sibir', Ural. Moscow: Sobranie, 2009. Print.

---. Kollektivizatsiia i raskulachivanie. Moscow: Magistr, 1996. Print.

---. Repressivnaia politika sovetskoi vlasti v derevne, 1928-33. Moscow: IRI-RAN, 2000. Print.

Jasny, Naum. The Socialized Agriculture of the USSR: Plans and Performance. Stanford: Stanford UP, 1949. Print.

Kane, Penny. Famine in China, 1959-61: Demographic and Social Implications. New York: Macmillan, 1988. Print.

Kessler, Gijs. "The Passport System and State Control over Population Flows in the Soviet Union." Cahiers du Monde russe 42. 2-4 (2001): 477-504. Print.

---. "The Peasant and the Town: Rural-Urban Migration in the Soviet Union, 1929-1940." Diss. European University Institute, 2001. Print.

Khanin, G. I. Dinamika ekonomicheskogo razvitiia SSSR. Novosibirsk: Nauka, 1991. Print. 
Khlevniuk, Oleg V. The History of the Gulag from Dekulakization to the Great Terror. New Haven: Yale UP, 2004. Print.

---. Master of the House: Stalin and his Inner Circle. New Haven: Yale UP, 2009. Print.

---. Stalin: New Biography of a Dictator. New Haven: Yale UP, 2015. Print.

---. "Stalin, Syrtsov, Lominadze: Preparations for the 'Second Great Breakthrough."' The Lost Politburo Transcripts: From Collective Rule to Stalin's Dictatorship. Ed. Paul R. Gregory and Norman Naimark. New Haven: Yale UP, 2008. 78-96. Print.

---, and R. W. Davies “The End of Rationing in the Soviet Union, 1934-1935." Europe-Asia Studies 51.4 (June 1999): 557-609. Print.

Khrushchev, Sergei, ed. Memoirs of Nikita Khrushchev.Vol. 2. Reformer (1945-1964). University Park: Penn State UP, 2006. Print.

Kindler, Robert. Stalins Nomaden: Herrschaft und Hunger in Kasachstan. Hamburg: Hamburger Edition, 2014. Print.

Klid, Bohdan, and Alexander J. Motyl, eds. The Holodomor Reader: A Sourcebook. Edmonton and Toronto: Canadian Institute of Ukrainian Studies Press, 2012. Print.

Kondrashin, Viktor V. Golod 1932-1933 godov: Tragediia rossiiskoi derevni. Moscow: Rosspen, 2008. Print.

--- and Diana Penner. Golod: 1932-33 gody v sovetskoi derevne (na materialakh Povol'zhia, Dona i Kubani). Samara and Penza, 2002. Print.

Kondrashine, Victor [Viktor Kondrashin], V. La famine en URSS, 1929-1934. Paris: AEHREE, 2013. Print.

Kopelev, Lev. The Education of a True Believer. New York: Harper and Row, 1980. Print.

Kravchenko, Victor. I Chose Freedom. New York: Scribner's, 1946. Print.

Kueh, Y. Y. Agricultural Instability in China, 1931-1991: Weather, Technology, and Institutions. Oxford: Clarendon Press, 1995. Print.

Kul'chyts'kyi, Stanislav. Chervonyi vyklyk: Istoriia komunizmu v Ukraïni vid ioho narodzhennia do zahybeli. Vol. 2. Kyiv: Tempora, 2013. Print.

---. Holod 1932-1933 rr. v Ukraïni iak henotsyd: Trudnoshchi usvidomlennia. Kyiv: Nash chas, 2008. Print.

---. Holodomor 1932-1933 rr v Ukraïni: Prychyny i naslidky. Kyiv: Instytut istoriï Ukraïny, NAN Ukraïny, 1995. Print.

---. Ukraïna mizh dvoma viinamy, 1921-1939 rr. Kyiv: Al'ternatyvy, 1999. Print.

---. Ukraïns'kyi Holodomor v kontektsi polityky Kremlia pochatku 1930-kh rr. Kyiv: Instytut istorii Ukrainy, NAN Ukraïny, 2014. Print.

---, ed. Kolektyvizatsiia i holod na Ukraini, 1929-1933: Zbirnyk dokumentiv i materialiv. Kyiv: Naukova dumka, 1992. Print. 
---. "The Holodomor of 1932-33: How and Why?" East/West: Journal of Ukrainian Studies 2.1 (2015): 93-116. Web. DOI: http://dx.doi.org/10.21226/T23K51.

Ledeneva, Alena. V. Russia's Economy of Favours: Blat, Networking and Informal Exchange. Cambridge: Cambridge UP, 1998. Print.

Levi, Primo. I sommersi e i salvati. Turin: Einaudi, 1986. Print.

Lewin, Moshe. "Taking Grain: Soviet Policies of Agricultural Procurements before the War." The Making of the Soviet System: Essays in the Social System of Interwar Russia. New York: Pantheon Books, 1985. 142-77. Print.

---. "The Disappearance of Planning in the Plan." Slavic Review 32.2 (June 1973): 271-87. Print.

---. "Who Was the Soviet Kulak." The Making of the Soviet System: Essays in the Social System of Interwar Russia. New York: Pantheon Books, 1985. 121-41. Print.

Li, Wei, and Dennis Tao Yang. "The Great Leap Forward: Anatomy of a Central Planning Disaster." Journal of Political Economy 113.4 (August 2005): 840-77. Print.

Li, Zhisui. The Private Life of Chairman Mao: The Memoirs of Mao's Personal Physician. Trans. Tai Hung-Chao. London: Chatto \& Windus, and New York: Random House, 1994. Print.

Liber, George O. Total Wars and the Making of Modern Ukraine, 1914-1954. Toronto: University of Toronto Press, 2016.

Lin, Justin Yifu. "Collectivization and China's Agricultural Crisis in 19591961." Journal of Political Economy 98.6 (Dec. 1990): 1228-52. Print.

Louw, Stephen. "In the Shadow of the Pharaohs: The Militarization of Labour Debate and Classical Marxist Theory." Economy and Society 29.2 (2000): 239-63. Print.

Luciuk, Lubomyr, ed., with the assistance of Lisa Grekul. Holodomor: Reflections on the Great Famine of 1932-1933 in Soviet Ukraine. Kingston, Ont.: Kashtan Press, 2008. Print.

Lytvyn, Volodymyr M., ed. Holod 1932-33 rokiv v Ukraini: Prychyny ta naslidky Kyiv: Naukova dumka, 2003. Print.

Lyons, Eugene. Assignment in Utopia. New York: Harcourt, Brace, 1937. Print.

Mace, James E. Communism and the Dilemmas of National Liberation: National Communism in Ukraine, 1918-1933. Cambridge, Mass.: Harvard Ukrainian Research Institute, 1983. Print.

---, and Leonid Heretz, eds. Investigation of the Ukrainian Famine, 19321933. Oral History Project of the Commission on the Ukraine Famine. 3 vols. Washington, D.C.: G.P.O., 1990. Print. 
MacFarquhar, Roderick. The Origins of the Cultural Revolution. 3 vols. New York: Columbia UP, 1974-97. Print.

Maksudov, Sergei [A. Babyonyshev]. "Dehumanization: The Change in the Moral and Ethical Consciousness of Soviet Citizens as a Result of Collectivizaion and Famine." After the Holodomor: The Enduring Impact of the Great Famine in Ukraine. Ed. Andrea Graziosi et al. Cambridge, Mass. Ukrainian Research Institute, Harvard University, 2013. 123-148. Print.

---. Poteri naseleniia SSSR. Benson, Vt.: Chalidze Publications, 1989. Print.

---. "Dehumanization: The Change in the Moral and Ethical Consciousness of Soviet Citizens as a Result of Collectivizaion and Famine." After the Holodomor: The Enduring Impact of the Great Famine in Ukraine. Ed. Andrea Graziosi, Lubomyr Hajda, and Halyna Hryn. Cambridge, Mass. Ukrainian Research Institute, Harvard University, 2013. 123-48. Print.

Makuch, Andrij, and Frank E. Sysyn, eds. Contextualizing the Holodomor: The Impact of Thirty Years of Ukrainian Famine Studies. Edmonton and Toronto: Canadian Institute of Ukrainian Studies Press, 2015. Print.

Maniak, Volodymyr, and Lidiia Kovalenko, eds. 33: Holod. Narodna knyhamemorial. Kyiv: Radians'kyi' pys'mennyk, 1991. Print.

Manning, Kimberley Ens., and Felix Wemheuer, eds. Eating Bitterness: New Perspectives on China's Great Leap Forward and Famine. Vancouver: UBC Press, 2011. Print.

MAPA Digital Atlas of Ukraine: The Great Famine Project. Web. http://gis.huri.harvard.edu/the-great-famine.html.

Martin, Terry. The Affirmative Action Empire: Nations and Nationalism in the Soviet Union, 1923-1939. Ithaca: Cornell UP, 2001. Print.

Medvedev, Zhores. Soviet Agriculture. New York: Norton, 1987. Print.

Meslé, France, and Jules Vallin. Mortalité et causes de décès en Ukraine au XXe siècle. Paris: INED, 2003. Print.

Middell, Matthias, and Felix Wemheuer, eds. Hunger and Scarcity under State-Socialism. Leipzig: Leipziger Universitätsverlag, 2012. Print.

Millar, James R. "Mass Collectivization and the Contribution of Soviet Agriculture to the First Five-Year Plan: A Review Article." Slavic Review 33.4 (Dec. 1974): 750-66. Print.

Moine, Nathalie. "Passeportisation, statistique des migrations et contrôle de l'identité sociale." Cahiers du Monde russe 38.4 (1997): 587-99. Print.

Murin, Iurii, ed. Pisatel' i vozhd': Perepiska M. A. Sholokhova s I. V. Stalinym. Sbornik dokumentov iz lichnogo arkhiva I. V. Stalina. Moscow: Raritet, 1997. Print.

Naimark, Norman. "Perspectives." Journal of Cold War Studies 14.3 (Summer 2012): 155-69. Print.

---. Stalin's Genocides. Princeton: Princeton UP, 2010. Print. 
---. "How the Holodomor Can Be Integrated into our Understanding of Genocide." East/West: Journal of Ukrainian Studies 2.1 (2015): 117-132. Web. DOI: http://dx.doi.org/10.21226/T2PP4Z.

Noll, Vil'iam [William]. Transformatsiia hromadians'koho suspil'stva: Usna istoriia selians'koi kul'tury 1920-30 rokiv. Kyiv: Tsentr doslidzhen' usnoï istoriï ta kul'tury "Rodovid," 1999. Print.

Ohayon, Isabelle. La sédentarisation des Kazakhs dans l'URSS de Staline: Collectivisation et changement social, 1928-1945. Paris: Maisonneuve et Larose, 2006. Print.

Omarbekov, Talas. Zobalang: Kushtep uzhymdastyrugha qarsylyq 1929-31 zhyldary bolghan khalyq narazylyghy. Almaty: Sanat, 1994. Print.

---. 20-30 zhyldardaghy Qazaqstan qasireti. Almaty: Sanat, 1997. Print.

Osokina, Elena A. Ierarkhiia potrebleniia: O zhizni liudei $v$ usloviiakh stalinskogo snabzheniia, 1928-1935 gg. Moscow: Izdatel'stvo MGOU, 1993. Print.

---. Our Daily Bread: Socialist Distribution and the Art of Survival in Stalin's Russia, 1927-1941. Armonk, N.Y.: M. E. Sharpe, 2001. Print.

---. Zoloto dlia industrializatsii: Torgsin. Moscow: ROSSPEN, 2009. Print.

Pantsov, Alexander. Mao: The Real Story. New York: Simon \& Schuster, 2012. Print.

Patenaude, Bertrand M. The Big Show in Bololand: The American Relief Expedition to Soviet Russia in the Famine of 1921. Stanford: Stanford UP, 2002. Print.

Pianciola, Niccolò. "Famine in the Steppe: The Collectivization of Agriculture and the Kazak Herdsmen, 1928-1934." Cahiers du Monde russe 45.1-2 (2004): 137-92. Print.

---. "Sacrificing the Kazakhs: The Stalinist Hierarchy of Consumption and the Great Famine in Kazakhstan of 1931-33." Thirty Years of Crisis: Empire, Violence, and Ideology in Eurasia from the First to the Second World War. Ed. Tomohiko Uyama. Sapporo: Slavic-Eurasian Research Center. Forthcoming.

---. Stalinismo di frontiera: Colonizzazione agricola, sterminio dei nomadi e costruzione statale in Asia centrale, 1905-1936. Rome: Viella, 2009. Print.

Pidhainy, S. O. ed. The Black Deeds of the Kremlin: A White Book. 2 vols. Trans. Alexander Oreletsky and Olga Prychodko. Toronto: Ukrainian Association of Victims of Russian Communist Terror, 1953 (vol. 1) and Detroit: Democratic Organization of Ukrainians Formerly Persecuted by the Soviet Regime, 1955 (vol. 2). Print.

Pipes, Richard, ed., with the assistance of David Brandenberger. The Unknown Lenin: From the Secret Archive. New Haven: Yale UP, 1996. Print. 
Poliakov, Iu. A., ed. Naselenie Rossii v XX veke: Istoricheskie ocherki. Vol. 1. 1900-1939 gg. Moscow: ROSSPEN, 2000. Print.

Pyrih, Ruslan, et al., eds. Holodomor 1932-1933 rokiv v Ukraïni: Dokumenty i materialy. Kyiv: Vydavnychyi dim “Kyievo-Mohylians'ka akademiia," 2007. Print.

"Resolution on Certain Questions in the History of Our Party since the Founding of the People's Republic of China (Adopted by the Sixth Plenary Session of the Eleventh Central Committee of the Communist Party of China on June 27, 1981." Web. 13 April 2016. https://www.marxists.org/subject/china/documents/cpc/history/01. htm.

Rudnytskyi, Omelian, et al. "Demography of a Man-Made Human Catastrophe: The Case of Massive Famine in Ukraine, 1932-1933." Canadian Studies in Population 42.1-2 (2015): 53-80. Print. https://ejournals.library.ualberta.ca/index.php/csp/article/view/2177 2/18080.

Rudych, F. M., et al, eds. Holod 1932-33 rokiv na Ukraini ochyma istorykiv, movoiu dokumentiv. Kyiv: Vydavnytstvo politychnoi literatury Ukrainy, 1990. Print.

Schoenhals, Michael. Saltationist Socialism: Mao Zedong and the Great Leap Forward, 1958. Stockholm: Föreningen för orientaliska studier, 1987. Print.

Sen, Amartya. Poverty and Famines: An Essay on Entitlement and Deprivations. New York: Oxford UP, 1982. Print.

Serbyn, Roman, and Bohdan Krawchenko, eds. Famine in Ukraine, 19321933. Edmonton: Canadian Institute of Ukrainian Studies, 1986. Print.

Shapiro, Judith. Mao's War against Nature: Politics and the Environment in Revolutionary China. New York: Cambridge UP, 2001. Print.

Shearer, David. "Elements Near and Alien: Passportization, Policing, and Identity in the Stalinist State, 1932-1952." Journal of Modern History 76.4 (2004): 835-81. Print.

Simenon, Georges. "Peuples qui ont faim." Mes Apprentissages: Reportages, 1931-1946. Ed. Georges Simenon. Paris: Omnibus 2001. 854-954. Print.

Snow, Edgar. The Other Side of the River: Red China Today. New York: Random House, 1962. Print.

Sorokin, Pitirim A. Hunger as a Factor in Human Affairs. Trans. Elena P. Sorokin. Gainesville: University Presses of Florida, 1975. Print.

Stasiuk, Olesia. Henotsyd ukraïntsiv: Deformatsiia narodnoï kul'tury. Kyiv: Vydavnychyi dim "Stylos," 2008. Print.

Sysyn, Frank E. "The Ukrainian Famine of 1932-3: The Role of the Ukrainian Diaspora in Research and Public Discussion." Problems of 
Genocide. Ed. Levon Chorbajian and George Shirinian. Toronto: Zoryan Institute, 1997. 74-117. Print.

---. "Thirty Years of Research on the Holodomor: A Balance Sheet." East/West: Journal of Ukrainian Studies 2.1 (2015): 3-16. Web. DOI: http://dx.doi.org/10.21226/T26P4M.

Teiwes, Frederick C. China's Road to Disaster: Mao, Central Politicians, and Provincial Leaders in the Unfolding of the Great Leap Forward, 19551959. Armonk, N.Y.: M. E. Sharpe, 1999. Print.

---. "Peng Dehuai and Mao Zedong." The Australian Journal of Chinese Affairs 16 (1986): 81-98. Print.

Thaxton, Jr., Ralph A. Catastrophe and Contention in Rural China: Mao's Great Leap Forward Famine and the Origins of Righteous Resistance in Da Fo Village. New York: Cambridge UP, 2008. Print.

---. Force and Contention in Contemporary China: Memory and Resistance in the Long Shadow of the Catastrophic Past. New York: Cambridge UP, 2016.

Thireau, Isabelle. "Quand la violence contribue à la famine: Témoignages adressés à l'administration des lettres et des visites (1958-1962)." International Workshop "Famines soviétique et chinoise." Paris, 18 October 2013. Paper presentation.

Thom, Françoise. "Reflections on Stalin and the Holodomor." East/West: Journal of Ukrainian Studies 2.1 (2015): 81-92. Web. DOI: http://dx.doi.org/10.21226/T2TG6W.

Tiruneh, Andargachew. The Ethiopian Revolution, 1974-1987: A Transformation from an Aristocratic to a Totalitarian Autocracy. Cambridge: Cambridge UP, 1993. Print.

Vasyl'iev, Valerii, and Iurii Shapoval, eds. Komandyry velykoho holodu: Poizdky V. Molotova i L. Kahanovycha v Ukrainu ta na Pivnichnyi Kavkaz. 1932-1933 rr. Kyiv: Heneza, 2001. Print.

Vasyl'iev, V., N Vert [Werth], and S. Kokin, comps. Partiino-radians'ke kerivnytstvo USRR pid chas holodomoru 1932-1933 rr.: Vozhdi. Pratsivnyky. Aktyvisty. Zbirnyk dokumentiv ta materialiv. Kyiv: Instytut istoriï Ukrainy NAN Ukraïny, 2013. Print. http://history.org.ua/LiberUA/978-966-02-7011-4/978-966-02-70114.pdf.

Veselova, O. M., V. I. Marochko, and O. M. Movchan, eds. Holodomory v Ukraïni, 1921-1923, 1932-1933, 1946-1947. Kyiv: Instytut istorii Ukrainy NAN Ukraïny, 2000. Print. http://www.history.org.ua/ ?libid $=1520$.

Veselova, Oleksandra, M. et al, eds. Pamiat' narodu: Henotsyd v Ukraini holodom 1932-1933 rokiv: Svidchennia. 2 vols. Kyiv: Kalyta, 2009. Print. http://history.org.ua/LiberUA/978-966-8879-70-8/0.pdf 
http://history.org.ua/LiberUA/978-966-8879-70-8(2)/978-966-887970-8(2).pdf

Viola, Lynne. Peasant Rebels under Stalin: Collectivization and the Culture of Peasant Resistance. New York: Oxford UP, 1996. Print.

---. The Unknown Gulag: The Lost World of Stalin's Special Settlements. New York: Oxford UP, 2007. Print.

Watson, James L. "Feeding the Revolution: Public Mess Halls and Coercive Commensality in Maoist China." Governance of Life in Chinese Moral Experience. Ed. Everett Zhang, Arthur Kleinman, and Weiming Tu. London: Routledge, 2011. 33-46. Print.

Wemheuer, Felix "Dealing with Responsibility for the Great Leap Famine in the People's Republic of China." The China Quarterly 201 (2010): 176194. Print.

---. Famine Politics in Maoist China and in the Soviet Union. New Haven: Yale UP, 2014. Print.

---. "Feed the Cities by Starving the Countryside: Rural-Urban Relations in the Chinese Great Leap Forward, 1958-1962." International Workshop "Famines soviétique et chinoise." Paris, 18 October 2013. Paper presentation.

Werth, Nicolas. Cannibal Island: Death in a Siberian Gulag. Princeton, N.J.: Princeton UP, 2007. Print.

--- and Alexis Berelowitch. L'État soviétique contre les paysans: Rapports secrets de la police politique (Tcheka, GPU, NKVD), 1918-1939. Paris: Tallandier, 2011. Print.

---. "The Great Ukrainian Famine of 1932-33." Online Encyclopedia of Mass Violence. Web. 15 April 2016. http://www.sciencespo.fr/massviolence-war-massacre-resistance/fr/document/great-ukrainianfamine-1932-33

Wheatcroft, Stephen G. "Towards Explaining Soviet Famine of 1931-33: Political and Natural Factors in Perspective." Food and Foodways 12.2-3 (2004): 107-136. Print.

William, J. A. The Critique of Ultra-Leftism in China, 1958-1991. Stanford: Stanford UP, 1984. Print.

Xiao-Planes, Xiaohong. "Famine et commune populaire: Deng Zihui en 1958-1962." International Workshop "Famines soviétique et chinoise." Paris, 18 October 2013. Paper presentation.

Yang, Dali L. Calamity and Reform in China: State, Rural Society and Institutional Change since the Great Leap Forward. Stanford: Stanford UP, 1996. Print.

Yang, Dennis Tao. “China's Agricultural Crisis and Famine of 1959-1961: A Survey and Comparison to Soviet Famines." Comparative Economic Studies 50.4 (2008): 1-29. Print. 
Yang, Jisheng. Tombstone: The Untold History of Mao's Great Famine. New York: Ferrar, Straus, and Giroux, 2012. Print.

Yang, Zhongmei. Hu Yaobang. A Chinese Biography. Trans. William A. Wycoff. Armonk, N.Y.: M. E. Sharpe, 1988. Print.

Yefimenko, Hennadii. "The Kremlin's Nationality Policy in Ukraine after the Holodomor of 1932-33." After the Holodomor. Ed. Andrea Graziosi, Lubomyr A. Hajda, and Halyna Hryn. Cambridge, Mass.: Ukrainian Research Institute of Harvard University, 2013. 69-98. Print. Vol. 30 (2008) of Harvard Ukrainian Studies.

Zaleski, Eugène. Planning for Economic Growth in the Soviet Union, 19181932. Chapel Hill: U of North Carolina Press, 1971. Print.

---. Stalinist Planning for Economic Growth, 1933-1952. Chapel Hill: U of North Carolina Press, 1980. Print.

Zhao, Ziyang. Prisoner of the State: The Secret Journal of Zhao Ziyang. Trans. and ed. Bao Pu, Renee Chang, and Adi Ignatius. New York: Simon \& Schuster, 2009. Print.

Zhou, Xun. Forgotten Voices of Mao's Great Famine, 1958-1962: An Oral History. New Haven: Yale UP, 2013. Print

---, ed. The Great Famine in China, 1958-1962: A Documentary History. New Haven: Yale UP, 2012. Print.

Zima, V. F. Golod v SSSR 1946-1947 godov: Proiskhodzhenie i posledstviia. Moscow: Institut rossiiskoi istorii RAN, 1996. Print.

Zlepko, Dmytro. Der ukrainische Hunger-Holocaust: Stalins verschwiegender Völkermord 1932/33 an 7 Millionen ukrainischen Bauern im Spiegel geheimgehaltener Akten des deutschen Auswärtigen Amtes. Sonnenbühl: Helmut Wild, 1988. Print. 
(c) 2016 East/West: Journal of Ukrainian Studies (ewjus.com) ISSN 2292-7956 Volume III, No. 2 (2016) 